\title{
Demokrasi dan Organisasi Masyarakat Sipil: Malang Corruption Watch
}

\author{
Latifah $^{1}$, Dinda Larasati \\ latifahbedadewa@gmail.com,dindatan14@gmail.com
}

\begin{abstract}
Abstrak
Korupsi dan demokrasi merupakan dua hal yang terkait erat dimana korupsi selalu menjadi masalah dalam institusi demokrasi. Adanya distribusi kekuasaan dalam tiga lembaga tinggi demokrasi dan open policy system memberikan peluang besar bagi terjadinya kasus korupsi. Sementara, demokrasi memungkinkan terlibatnya aktor non-negara dalam pemerintahan salah satunya Organisasi Masyarakat Sipil (CSO). CSO berfungsi sebagai elemen kritis ketika pemerintah tidak mampu menjalankan pemerintahan dengan baik dalam menanggulangi isuisu tertentu termasuk korupsi. Sehingga, penelitian ini hendak menggambarkan peran CSO di tingkat pemerintah daerah yang menaruh perhatian pada peran MCW sebagai salah satu bentuk CSO dalam mengawal pilkada Batu tahun 2017. Tulisan ini merupakan jenis penelitian kualitatif deskriptif. Berdasarkan penelitian lapangan dan telaah pustaka, temuan penulis menunjukan bahwa CSO dianggap menjadi salah satu obat mujarab dalam menunjang sistem demokrasi yang ideal termasuk pilkada. Melalui pilkada Batu tahun 2017, $\mathrm{MCW}$ berperan dalam monitoring, investigasi, dan advokasi serta menemukan adanya kasus korupsi berupa; manipulasi dana kampanye oleh partai politik atau kandidat; penyalahgunaan dana dan sumber daya negara oleh partai politik atau kandidat dan politik uang.
\end{abstract}

Kata Kunci: CSO, MCW, Demokrasi, Korupsi

\begin{abstract}
Corruption and democracy are two closely related issues where corruption is always a problem in democratic institutions. The presence of power distribution in the three institutions of democracy and open policy system provides a great opportunity for corruption cases. Meanwhile, democracy allows the involvement of non-state actors in the government of one of the CSOs. CSOs serve as a critical element when governments are unable to run the government well in tackling certain issues including corruption. Thus, this research would like to describe the role of CSOs at the local government level that pay attention to the role of MCW as one form of CSO in escorting the Batu election in 2017. This paper is a descriptive qualitative research. Based on field research and literature review, the findings of the authors show that CSO is considered to be one of the elixirs in supporting the ideal democratic system including elections. Through the elections of Batu in 2017, MCW plays a role in monitoring, investigation, and advocacy and finds cases of corruption in the form of; manipulation of campaign funds by political parties or candidates; misuse of state funds and resources by political parties or candidates and money politics.
\end{abstract}

Keywords: CSO, MCW, Democracy, Corruption

\section{Pendahuluan}

Demokrasi sebagai sebuah sistem pemerintahan telah diadopsi oleh Indonesia sejak awal berdirinya bangsa ini. Pada masa orde lama dikenal dengan

\footnotetext{
${ }^{1}$ Korespondensi: Latifah. Program Studi Ilmu Hubungan Internasional. Universitas Muhammadiyah Malang. Gedung Kuliah Bersama (GKB) I. Jl. Raya Tlogomas No.246 Malang 65144. (0341)464318 26 Ext.248
} 
istilah demokrasi terpimpin dibawah Soekarno, meskipun dalam prakteknya sebagai sebuah pimpinan otoriter yang berada dibalik "tirai" demokrasi. Selanjutnya, orde baru yang berada dibawah kepemimpinan Soeharto menjadikan demokrasi sebagi simbol kekuasaan Negara meskipun dalam prakteknya terdapat berbagai macam penyimpangan demokrasi (Alfitri, 2009). Beralih ke orde reformasi pada tahun 1999, euphoria praktek demokrasi ditandai dengan adanya pemilihan umum pertama di Indonesia yang diikuti oleh multipartai. Namun terjadi perkembangan dalam praktek demokrasi seiring dengan bertambahnya pengalaman demokrasi Indoensia dari masa ke masa namun masih terdapat berbagai kesenjangan, kemiskinan, kelaparan, permasalahan kesehatan tidak kunjung selesai ditengah masyarakat (Alfitri, 2009).

Faktor utama pendorong terjadinya kasus korupsi di Indonesia adalah implementasi sistem demokrasi. Banyak studi empiris menyimpulkan bahwa demokratisasi, sampai taraf tertentu, sebenarnya telah menciptakan kondisi yang menyuburkan penyebaran korupsi. Moran (2001) misalnya, berpendapat bahwa transisi menuju demokrasi, baik dalam bentuk sebuah transisi dari pemerintahan otoriter atau dari komunisme atau dalam proses dekolonisasi atau munculnya negarabangsa baru, mempunyai implikasi untuk perluasan korupsi. Dalam penelitian tentang proses demokratisasi di berbagai negara, Rose \& Shin (2001) juga berpendapat bahwa proses demokratisasi, sementara di satu sisi dapat menghasilkan keabsahan rezim demokratis; di sisi lain, ia memiliki potensi untuk mengembangbiakkan korupsi.

Temuan serupa juga dikelola oleh Bank Dunia (2000) ketika menganalisis Eropa Timur dan negara-negara bekas Uni Soviet, Bank Dunia menemukan bahwa lingkungan transisi demokrasi telah menciptakan lahan subur bagi korupsi karena 'proses transisi memberikan kekuasaan pada lembaga dan pejabat baru di tengah tengah redistribusi besar-besaran aset negara'. Dalam kasus demokratisasi di Indonesia, kasus korupsi yang terjadi sejak tahun 2001 sampai 2015 tercatat sebanyak 2321 kasus korupsi dengan jumlah terdakwa sebanyak 3109 (Liputan6, 2016).

Demokrasi menjadi lahan subur bagi kemunculan dan perkembangan CSO. Tanpa rezim demokratis yang memberikan kebebasan bagi rakyat, maka kemunculan dan perkembangan CSO menjadi mustahil. Hal ini dikembalikan pada pengertian dasar dari konsep demokrasi yang mengakar pada kata demos yang berarti pemerintahan dan cratos atau cretein yang berarti masyarakat sehingga menjadi 
pemerintahan yang dijalankan oleh rakyat (Santoso, 1998). Pada posisi ini, CSO mengambil peran terdepan karena aktor pemerintah dan aktor swasta umumnya apatis terhadap agenda anti korupsi karena mereka adalah kelompok yang memiliki kepentingan dalam isu ini. Disamping itu partai politik enggan memulai agenda antikorupsi, terutama jika agendatersebut berpotensi membahayakan kepentingannya (Hayden, Court \& Mease, 2004). Sehingga, peran CSO dalam hal ini sangat penting berfungsi sebagai elemen kritis pemerintah untuk memperjuangkan kepentingan public dan menjunjung tinggi nilai dan norma demokrasi. Dengan demikian, tulisan ini menaruh perhatian pada peran Malang Corupption Watch (MCW) dalam mengawal pemilihan umum kepala daerah di Kota Batu tahun 2017.

\section{Peran Organisasi Masyarakat Sipil (CSO) dalam Institusi Demokrasi}

Istilah "civil society organization" (CSO) atau dalam bahasa Indonesia menjadi Organisasi Masyarakat Sipil (OSM) adalah arena tempat asosiasi yang sekaligus sebagai agen berkompetisi untuk mempengaruhi dalam interaksinya dengan negara maupun organisasi antar pemerintah (Hyden, 1997). Asosiasi adalah sekumpulan orang yang cenderung memiliki kesamaan pandangan terhadap suatu isu yang kemudian membentuk sebuah OSM/CSO. Hyden (1998) mengelompokan CSO kedalam dua kategori yakni minimalis dan maximalis. Dalam pengertian minimalist, CSO adalah sekelompok orang (asosiasi) yang hanya secara politik dan sipil melindungi memperjuangkan serta menjunjung tinggi nilai dan norma demokratis dalam prakteknya. Sedangkan, dalam artian maximalis CSO adalah segala bentuk asosiasi dan organisasi non-negara yang ada dalam masyarakat. Sehingga dalam konteks ini, MCW termasuk kedalam salah satu bentuk CSO dengan kategori minimalist disebabkan karena asosiasi ini memiliki focus untuk menunjang implementasi demokrasi yang bersih dengan adanya akuntabilitas dan penanganan kasus korupsi demi kepentingan public.

CSO memiliki setidaknya lima karakteristik yang mencirikannya untuk memudahkan dalam identiffikasi keberadaannya ditengah masyarakat sosial, sebagaimana disebutkan oleh (Soeharko, 2003) yakni pertama bahwa CSO lebih cendrung memiliki tujuan terkait isu yang berhubungan dengan tujuan public daripada privat. Kedua, CSO berhubungan dengan negara sebagai aktor dominan 
namun tidak dengan tujuan untuk mengambil alih kekuasaan pemerintahan dalam Negara. Selanjutnya, CSO juga lebih memperjuangkan pluralism dalam masyarakat yang demokratis daripada menjadi kelompok fundamentalis agama dan lainnya. Keempat, CSO merepresentasikan kepentingan kelompok bukan kepentingan utuh perorangan terkait isu yang difokuskan. Terakhir, CSO tidak sama dengan civic community sebagaimana disebutkan oleh Putnam (1993) yang berada dalam Negara demokrasi maju. Berdasarkan karakteristik diatas, MCW sudah bisa dikategorikan sebagai salah satu bentuk CSO karena memenuhi lima indikator tersebut yang akan dipaparkan secara detail tentang MCW pada sub bahasan selanjutnya.

Dalam relasi antara peran CSO dan institusi demokrasi, CSO sebagai aktor yang berpartisipasi sebagai 'reformist' dalam institusi demokrasi. Hal ini diindikasikan dengan besarnya peran CSO dalam beberpa proses transformasi demokrasi di negara-negara berkembang sebagaimana diakui dalam beberapa sumber yang berbica terkait demokratisasi (O'Donnell \& Schmitter 1986; Rueschemeyer, Stephens \& Stephens 1992; Haynes 1997). Disamping itu, CSO juga memiliki peran yang cukup penting sebegai kelompok penekan pemerintah atau disebut sebagai elemen kritis pemerintah. CSO memainkan peran yang cukup penting meskipun tidak secara langsung menjadi bagian dari pemerintah sebagaimana dipaparkan pada paragraph sebelumnya. Salah satu contohnya terkait isu korupsi dalam institusi negara demokrasi, aktor negara lebih cendrung, aktor negara lemah atau tidak mampu memainkan perannya dalam memerangi korupsi.

Lebih jauh, CSO dianggap sebagai obat mujarab dalam institusi demokrasi guna mendorong terciptanya tata kelola pemerintahan yang baik. CSO memiliki modal yang potensial untuk menjad efektif dalam mengawal pemerintahan yang sarat akan nilai demokratis terkhusus dalam memerangi isu korupsi yang umumnya menjadi permasalahan tiap Negara demokrasi. Modal yang dimaksudakan adalah CSO umumnya tidak mempunyai niat untuk memperoleh kekuasaan politik, dan karenanya dapat mengungkapkan yang lebih tulus untuk kepentingan publik (Pietrzyk 2003). Dengan kondisi ini, CSO berfungsi sebagai badan independen alternatif untuk menerapkan tekanan untuk mekanisme akuntabilitas dalam struktur hubungan kekuasaan pemerintah. 
Terkait hubungan antara demokrasi dan peran CSO didalamnya, Larry Diamond (2005) secara sistematis menyebutkan ada enam kontribusi civil society terhadap proses demokrasi. Pertama, penyedia wahana sumber daya politik, ekonomi, kebudayaan dan moral untuk mengawasi dan menjaga keseimbangan pejabat negara. Kedua, pluralism yang terdapat dalam masyarakat madani menjadi dasar penting bagi persaiangan demokratis jika terorganisir. Ketiga, kewarganegaraan. Keempat, turut serta dalam menjaga stabilitas Negara. Kelima, menjadi wahana pendidikan pimpinan politik. Keenam, menghalangi dominasi rezim otoriter dan mempercepat runtuhnya rezim (Diamond, 2005). Kuatnya kaitan civil society dengan demokrasi, civil society dipercaya sebagai obat mujarab bagi demokrasi terutama di negara yang demokrasinya mengalami ganjalan akibat kuatnya hegemoni negara. Mengacu pada pemahaman tersebut, tentunya MCW memiliki peran dalam menunjang terlaksananya proses demokrasi yang sehat.

\section{Metode}

Tulisan ini merupakan penelitian kualitatif deskriptif. Teknik pengumpulan data dilaksanakan melalui metode observasi, wawancara, dan telaah pustaka. Hasil wawancara digunakan sebagai data primer dan didukung dengan data kepustakaan yang bersumber dari buku, jurnal, berita daring sebagai sumber data sekunder.

Data yang diperoleh dari observasi, hasil wawancara, dan studi kepustakaan kemudian dianalisa melalui langkah-langkah sebagai berikut. Langkah pertama yaitu pengolahan data dengan tujuan agar data yang telah diperoleh dapat diolah kembali sehingga data menjadi lebih sederhana dan dapat disajikan dengan lebih baik dan rapi sehingga lebih mudah untuk dianalisis. Langkah berikutnya adalah analisis data dimana pada tahap ini data yang telah diolah disederhanakan lagi agar lebih mudah dipahami dan ditafsirkan yang di intepretasikan dalam bentuk kalimat. Langkah terakhir yaitu penafsiran hasil analisis untuk menarik kesimpulan dari penelitian kualitatif yang telah dilakukan.

\section{Hasil dan Pembahasan}


MCW adalah sebuah Lembaga Swadaya Masyarakat Anti Korupsi yang berawal dari komunitas diskusi yang terdiri dari kumpulan kecil aktivis yang sudah berjalan sebelum reformasi 1998. MCW resmi berubah menjadi LSM pada 31 Mei 2000 dan terinspirasi oleh adanya Indonesia Corruption Watch (ICW). MCW menjadi rujukan publik dan media massa di Malang Raya terkait kasus korupsi yang terjadi di wilayah Malang Raya yang meliputi Kabupaten Malang, Kota Malang, dan Kota Batu (Malang Corruption Watch, 2014). Dalam pembahasan ini, MCW diyakini berperan besar dalam menunjang terlaksananya proses demokrasi yang sehat. Hal ini terlihat dengan bidang gerak MCW yang berfokus pada permasalahan korupsi yang secara umum dikelompokan dalam tahapan monitoring, advokasi dan investigasi.

\section{Struktur Organisasi MCW}

Pembentukkan MCW tidak terlepas dari pecahnya reformasi di tahun 1998 yang membuka kebebasan terhadap forum-forum, kelompok-kelompok diskusi, gerakan-gerakan dan sebagainya. Pasca revolusi tahun 1998 yang menumbangkan rezim otoriter orde baru yang mengekang kebebasan rakyat, muncul komunitaskomunitas terutama dikalangan mahasiswa. Salah satunya yaitu MCW yang awalnya merupakan komunitas diskusi yang kemudian resmi berubah menjadi Lembaga Swadaya Masyarakat pada 31 Mei 2000 yang memiliki tanggungjawab besar dalam mendorong tatanan birokrasi yang bebas dari korupsi dan nepotisme serta bergerak dalam upaya pemberantasan korupsi di daerah (MCW Malang, 2017). Oleh karena itu, MCW dapat dikatakan sebagai pelopor gerakan antikorupsi pasca reformasi tahun 98.

MCW membentuk kader-kadernya dengan merekrut anggota secara selektif, kemudian membekalinya dengan kemampuan dasar seorang penyidik/investigator, peneliti, penulis, analis data melalui program-program yang disusun MCW seperti membentuk sekolah pikada relawan mahasiswa dan dikoordinatori oleh unit korupsi politik dan kebijakan publik sebagai tim khusus yang ikut terlibat langsung dalam monitoring. Pada awalnya, sekolah pilkada terdiri dari 50 orang dari beberapa mahasiswa universitas di Malang yang memiliki ketertarikan dalam kasus korupsi. Sekolah pilkada ini memiliki rangkaian yakni pada satu minggu pertama merupakaan pembekalan materi terkait demokrasi lokal, materi gerakan dan 
pentingnya pemantauan. Program MCW yang lainnya yaitu diskusi publik yang dalam kegiatan ini dihadiri oleh beberapa tokoh masyarakat dan mahasiswa yang pro terhadap gerakan anti korupsi (Sukowiyono \& Sulistiani, 2014).

Selain itu, MCW memiliki penerbitan yang telah mempublikasikan banyak buku dan buletin anti korupsi. Hal ini sesuai dengan klaim yang mengatakan MCW bukan hanya sebagai penampung data dan aspirasi melawan koruptor tetapi juga sebagai sentral pendidikan anti korupsi (Jurnal Malang, 2015). Namun, masih terdapat tantangan yang harus di hadapi oleh MCW salah satunya yaitu sejumlah indikasi pungli banyak terjadi yang mengakibatkan kurang maksimalnya advokasi di bidang pendidikan anti korupsi.

Capaian MCW antara lain yaitu terlibat dan berperan dalam beberapa monitoring, advokasi, dan investigasi kasus korupsi yang terjadi di Malang seperti kasus pungli di dunia pendidikan kota Malang, korupsi pengadaan lahan RSUD Kota Malang, denda drainase Jalan Tidar senilai Rp 39 miliar yang molor dari target, dugaan korupsi jembatan Kedungkandang senilai Rp 9,7 miliar, dugaan korupsi pengadaan buku perpustkaan kelurahan senilai Rp 2,2 miliar, dugaan penggelapan pajak 2012 sebesar Rp 4,6 miliar,pungutan liar SMA 10 sebesar Rp 2,25 miliar, dan juga kasus korupsi yang terjadi dalam pilkada (Surabaya Pagi, 2014). Dalam membongkar kasus korupsi yang terjadi di Malang Raya MCW telah mendapatkan dukungan dari ICW berupa pengawalan. Sehingga, dalam perkembangannya, MCW telah tumbuh menjadi organisasi masyarakat sipil yang ditakuti oleh para koruptor karena selalu vokal menghadapi kasus korupsi yang terjadi di Malang Raya.

\section{Peran MCW: Monitoring, Investigasi dan Advokasi}

Berdasarkan hasil wawancara, MCW sebagai civil society berperan sebagai penyedia wahana sumber daya politik, ekonomi, kebudayaan dan moral untuk mengawasi dan menjaga keseimbangan pejabat Negara. Hal ini telah banyak dilakukan oleh MCW sebagaimana bidang gerakknya yakni monitoring dan investigasi berbagai macam kegiatan yang dilakukan oleh pejabat baik melalui proyek maupun kebijakan yang terindikasi kasus korupsi. Diantara kasus yang ditangani MCW adalah korupsi pada pilkada kota batu 2017, moitoring pilkada kota Malang yang segera dilakukan 2018, advokasi dan mengawal pembangunan Mall Dinoyo, 
kasus dugaan korupsi pengadaan lahan RSUD Kota Malang dan beberapa deret kasus korupsi lainnya (Nursasi, 2017).

MCW dalam melakukan monitoring terhadap proses pelaksanaan pilkada Kota Batu 2017 dibagi kedalam tiga tahap sebagaimana di paparkan oleh Atha Nursasi, anggota unit korupsi politik dan kebijakan publik. Tahap satu merupakan pra pelaksanaan pemilihan yang meliputi; launching Komisi Pemilihan Umum (KPU) kota Batu; penetapan calon; riset LHKPN dan pembentukan sekolah pilkada. Tahapan kedua yang meliputi debat kandidat, kampanye setiap calon dan hari pencoblosan. Sedangkan tahap tiga (pasca pemilu) meliputi pelaporan alokasi anggaran pemilu oleh masing-masing calon dan pengawalan oleh MCW (Nursasi, 2017).

MCW memonitoring setiap tahapan pilkada. Monitoring dilakukan sejak awal launching KPU oleh pemerintah kota Batu pada 30 Juli 2016. Perwakilan dari KPU Batu yaitu Ketua KPU, Anggota Divisi Sosialisasi dan Partisipasi Pemilih dan Pengembangan Informasi, serta didampingi oleh dua Kasubbag (KPU Kota Batu, 2016). Dalam launching ini, diberikan pemaparan terkait visi misi kerja KPU untuk pelaksanaan pilkada ini. Diterangkan bahwa KPU kota batu (2017) memiliki visi dan misi secara umum adalah mewujudkan KPU yang kredibilitas dan kapabilitas, pemilu yang bebas, rahasia, jujur, adil, akuntabel, edukatif dan beradab, meningkatkan kualitas pemilu yang bersih, efisien dan efektif; dan meningkatkan kesadaran politik rakyat untuk berpartisipasi aktif dalam pemilu demi terwujudnya cita-cita masyarakat Indonesia yang demokratis.

MCW terlibat langsung ditengah acara launching KPU untuk melihat dan mengamati terkait komitmen yang disampaikan melalui visi dan misinya. Selanjutnya, ini akan menjadi acuan kinerja KPU selama proses eufora pesta demokrasi tersebut. Berdasarkan pengamatan tim MCW ditemukan terdapat beberapa ketidak-sesuaian antara komitmen yang dilontarkan dengan aplikasi di lapangan. Nursasi (2017), menggambarkan diantaranya terkait pendidikan publik untuk meningkatkan kesadran politik rakyat sangat minim dilakukan. Hampir setiap sosialisasi yang dilakukan oleh KPU hanya sebatas mekanisme pencoblosan. Disamping itu, komitmen KPU untuk menyelenggarakan pemilu yang bebas, rahasia, jujur, adil, akuntabel, edukatif dan beradab, meningkatkan kualitas pemilu yang bersih, efisien dan efektif belum mampu 
diaplikasikan dengan maximal. Tim MCW menemukan dalam pelaksanaan kampaye dan pencoblosan, KPU tidak tegas menindak pelanggaran yang akan dijelaskan pada bagian selanjutnya. Tim MCW menduga sikap pasif KPU ini tidak bisa dilepaskan dengan beberapa permainan aktor terselubung dibelakangnya.

Penetapan calon juga turut dimonitoring oleh tim MCW dan selanjutnya mengadakan riset terkait LHKPN masing-masing calon. Pemeriksaan LHKPN ini guna mengetahui sumber dana dan kapabilitas paslon jika dilihat dari kepemilikan materi. Yang berdasarkan hasil wawancara dengan pihak yang secara langsung menyentuh kasus pilkada ini, Nursasi (2017) mengaku bahwa sulit untuk memetakan naik turunnya LHKPN setiap paslon dikarenakan kekayaan tidak dilaporkan sesuai dengan prosedur tiap tahunnya. Masing-masing calon hanya melaporkan kekayaan pada tahun 2016 saat pencalonan sebagai walikoa Batu, kecuali paslon nomor dua yang sudah melaporkan sejak 2014 disebabkan kekikutsertaanya dalam pilkada kota Malang 2015. Secara umum, LHKPN setiap calon cukup besar namun sama sekali tidak terjadi penurunan dari tahun sebelumnya meskipun telah mengeluarkan beberapa uang selama proses kegiatan pilkada berdasarkan data 2017.

Selanjutnya, tim MCW membentuk sekolah pikada relawan mahasiswa yang dikoordinatori oleh unit korupsi politik dan kebijakan publik sebagai tim khusus yang terlibat langsung dalam pengawalan pilkada ini. Maulana (2017) menerangkan bahwa pada tahap awala anggota sekolah pilkada terdiri dari 50 orang dari beberapa mahasiswa universitas di Malang yang memiliki ketertarikan dalam kasus korupsi. Rnagkaian kegiatan sekolah ini meliputi, satu minggu pertama merupakan pembekalan materi terkait demokrasi lokal, materi gerakan dan pentingnya pemantauan. Setelah itu, dilanjutkan dengan pemantauan langsung, pemantauan medsos, update berita pilkada, analisis visi misi masing-masing calon, kapasitas pasangan calon (paslon) yg dlihat dari debat dan riset kebutuhan masyarakat kota Batu. Adapun pemantauan tersebut dimulai sejak November 2016 sampai februari 2017.

Disamping itu, Maulana (2017) menjelaskan bahwa tim MCW juga memberikan pendidikan publik kepada masyarakat terkait demokrasi lokal guna meningkatkan kesadaran dan pemahaman masyarakat tentang pentingnya partisipasi masyarakat dalam pemilu, pelaksanaan pemilu yang bersih dan menyukseskan 
demokrasi lokal yang sehat. Hal ini dilakukan melalui diskusi yang dilakukan pada beberapa tempat, aksi turun jalan oleh tim MCW dan anggota sekolah pilkada seperti aksi tolak money politik secara langsung maupun melalui media sosial, televisi, radio, media cetak dan online (Malangtoday, 2016).

Tahap dua meliputi kampanye, debat kandidat, dan hari pencoblosan. pengawalan yang dilakukan dengan ikut terlibat memantau setiap kampanye yang dilakukan oleh masing-masing calon. KPU telah menetapkan jadwal kampanye bagi setiap paslon dan tidak diperkenankan bagi paslon untuk melaksanakan kampanye diluar jadwal yang ditentukan. KPU telah memberikan hak yang sama kepada setiap paslon sebanyak 70 kali dalam jangka waktu 108 hari yang dimulai dari tanggal 28 Oktober 2016 hingga 11 Februari 2017 (KPU Kota Batu, 2016).

Berdasarkan hasil wawancara dengan Nursasi (2017) menyatakan hasil pengamatan tim MCW, ditemukan bahwa seluruh paslon beberapa kali melakukan kampanye diluar jadwal yang ditentukan. Disamping itu, tidak jarang ditemukan beberapa paslon melakukan kampanye pada waktu yang sama dengan kampanye yang dilakukan oleh paslon lain. Ini salah satunya untuk mengurangi jumlah peserta kampanye pada paslon yang memiliki jadwal kampanye (kampanye terselubung). Potensi besar bagi setiap paslon untuk mengumbar keburukan paslon lain. Ditambah dengan pembagian sticker tertentu yang melambangkan paslon ditambah money politik dalam setiap kampanye yang dilakukan umumnya dalam bentuk pembagian uang tunai dan sembako.

Tim MCW juga monitoring dalam pelaksanaan debat publik antar paslon yang dilakukan 3 kali. Debat publik pertama dilaksanakan sabtu, 10 desember 2016 yang disiarkan langsung oleh Batu TV bertemakan kesejahteraan masyarakat dan memajukan daerah ini yang kemudian terbagi dalam 6 segmen (KPU Kota Batu, 2016). Sedangkan debat public kedua dilaksanakan pada 14 januari 2017 yang diadakan di hotel Shingasari dan disiarkan langsung oleh JTV, setiap paslon menyampaikan visi misi masing-masing untuk 5 tahun kedepan (KPU Kota Batu, 2016). Debat publik ketiga sekaligus terakhir dilaksanakan pada 11 Februari 2017, H2 pencoblosan.

MCW mengunjungi kantor KPU kota Batu sebagai tindak lanjut dari kegiatan monitoring yang dilakukan pada debat publik yang pertama. Mansyur (2017) 
menyatakan bahwa kedatangannya bertujuan untuk memberikan analisa terkait komitmen yang disampiakan oleh paslon berdasarkan data-data korupsi dan sumberdaya alam kota Batu. Menurutnya, setiap paslon sangat minim terhadap tindakan yang akan diberikan terhadap kasus korupsi. Disamping itu, minimnya perhatian yang akan diberikan terhadap pengolahan dan pemberdayaan sumber daya alam kota Batu. Ia juga menitipkan beberapa pertanyaan terkait kasus korupsi dan SDA kota Batu (KPU Kota Batu, 2017).

Dalam debat publik kedua, tim MCW melakukan analisa terkait visi-misi yang disampaikan oleh seluruh paslon. Wawancara yang dilakukan dengan Nursasi (2017) menjelaskan bahwa kualitas visi misi yang disampaikan sangat minim bahkan kurang menyentuh kebutuhan dasar masyarakat kota Batu. Sebelumnya, pada tahap satu tim relawan sekolah pilkada telah melakukan riset kebutuhan masyarakat yang dijadikan sebagai data acuan perbandingan visi misi setiap paslon. Berdasarkan hasil riset, diketahui bahwa kebutuhan masyarakat kota Batu adalah sangat bergantung pada sektor pertanian dan pengembangan sumber daya alam. Hal ini sesuai dengan kondisi geografis kota batu yang cendrung cocok untuk wilayah pertanian karena berada pada dataran tinggi dan pegunungan. Namun, setiap paslon sangat minim menyentuh hal tersebut dalam visi misi namun lebih banyak berfokus pada pengembangan pariwisata. Hasil wawancara dengan Nursasi (2017) memaparkan kapasitas dan kapabilitas masing-masing paslon belum memadai untuk menjadi pemimpin kota Batu. Hal ini karena minimnya perhatian terhadap kebutuhan masyarakat yang sudah terlihat sejak penyampaian visi misi (KPU Kota Batu, 2017). Selain itu, setiap paslon saling menyerang (adu mulut) pada saat debat public berdampak terhadap opini dan persepsi masyarakat karena framing media(missal batu TV, JTV) yang mempengaruhi persepsi masyarakat. Akibatnya, paslon ke-2 Dewanti Rumpoko menjadi calon yang popular meskipun secara kapabilitas dan gagasan yang disampaikan kurang masuk akal, Nursasi (2017)

Bagian selanjuutnya dalam tahap kedua ini adalah hari pencoblosan yang dijadwalkan pada Rabu 15 Februari 2017 (Suryamalang, 2016). Atha dan Maulana (2017) menyatakan bahwa terjadi beberapa pelanggaran suasana pada pencoblosan cukup mencekam. Menurutnya, pemilu seolah sudah dibentuk untuk memenangkan paslon nomor 2 dengan menggunakan legitimasi dari suaminya yang berstatus sebagai 
incumbent. Hal ini ditunjukan bahwa pada beberapa Tempat Pemungutan Suara (TPS) di daerah Bumi Aji secara terang terangan diarahkan untuk memilih paslon nomor 2. Lebih jauh, beberapa preman dan polisi (aparat) dikerahkan untuk mengarahkan masyarakat. Polisi bahkan menggunakan toa untuk mengerahkan masyarakat memilih secara serentak paslon nomor 2. Pada beberapa TPS serangan fajar pun masih terjadi. Serangan fajar merupakan istilah yang digunakan untuk money politik (pembagian uang tunai dan sembako) secara langsung pada saat hari pencoblosan. Hal ini dilakukan hamper oleh semua paslon pada beberpa TPS yang sudah mereka gadang menjadi pemenangan mereka.

Menurut Atha Nursasi, tim MCW yang sebelumnya sudah ditempatkan untuk monitoring pada beberapa TPS tertentu harus menghadapi aparat dan preman untuk memasuki arena TPS. Ia juga menuturkan bahwa sikap Panitia Pengawas Pemilu (panwaslu) cendrung sangat pasif melihat pelanggaran yang terjadi. Pihak MCW telah melakukan pelaporan berdasarkan data yang mereka sediakan namun tindakan KPU dan Panwaslu masih cendrung pasif (Nursasi dan Maulana, 2017). Menurut Divisi Hukum KPUD kota Batu, Mardiono (Detiknews, 2017), KPUD Kota Batu telah menerima Laporan Penerimaan dan Pengeluaran Dana Kampanye (LPPDK) semua pasangan calon, yang maju pada Pilwali Kota Batu periode 20172021.

Tim MCW dalam monitoring tahapan pelaporan alokasi dana yang dilakukan oleh setiap paslon mendapati beberapa kejanggalan. Hasil wawancara dengan Nursasi (2017) Laporan meliputi 3 tahap yakni Laporan awal (pendaftaran), Laporan kedua (penggunaan dana kampanye) Laporan tahap ketiga (pasca pilkada). Menurutnya, kejanggalan dalam pelaporan ini adalah bahwa pada laporan tahap kedua dan ketiga, tidak terjadi perubahan anggara sama sekali. LPPDK yang dilaporkan pada tahap kedua sama dengan LPPDK yang dilaporkan pada tahap ketiga yang seharusnya mengalami perubahan disebabkan dana yang dikeluarkan pada tahapan mulai dari pasca kampanye sampai akhir penetapan paslon terpilih tentunya mengeluarkan biaya meskipun tidak banyak seperti tahapan sebelumnya. Adapun detail laporan masing-masing paslon sebagaimana diterangkan oleh Mardiono pada media massa saat wawancara (Detiknews, 2017). Data tersebut menjadi bukti terkait penyalahgunaan dana negara. 


\section{Kesimpulan}

Kinerja MCW dilakukan melalui 3 (tiga) cara yakni monitoring, investigasi dan advokasi. Dalam kasus pilkada kota Batu 2017, MCW melakukan pengawalan yang secara umum dibagi kedalam 3 (tiga) tahap. Tahap monitoring antara lain dilaksanakan melalui launching KPU, penetapan calon, riset kebutuhan masyarakat kota Batu dan pembentukan sekolah pilkada. Tahap kedua, MCW melakukan monitoring pelaksanaan kampanye, debat publik dan pencoblosan. Sedangkan pada tahap tiga, monitoring hanya dilakukan pada pelaporan alokasi dana dan pengawalan. MCW menemukan beberapa pelanggaran selama proses pilkada Kota Batu antara lain meliputi manipulasi dana kampanye oleh oleh partai politik atau kandidat, penyalahgunaan dana dan sumber daya negara oleh partai politik atau kandidat dan politik uang.

MCW sebagai representasi CSO berperan besar dalam membantu upaya pemberantasan korupsi di wilayah Malang Raya. MCW menjadi elemen kritis pemerintahan Indonesia yang berusaha memperjuangkan dan menjunjung tinggi nilai akuntabilitas dalam pemerintahan demokratis. Oleh karenanya, munculnya CSO seperti MCW di kota-kota lainnya yang terus menjaga profesionalitasnnya diharapkan menjadi kontribusi besar dalam tata kelola pemerintahan yang baik.

\section{Daftar Rujukan}

\section{Buku}

Hyden, Goran, (1998). Building Civil Society At The Turn Of Millennium. Dalam John Burbidge. (Ed.), Beyond Prince And Marchant, New York: PACT Publication.

Hayden, Goran, (1997). (2003). Civil Society and Governance in 16 Developing Countries. London: World Governance Survey Discussion Paper.

Hutington, P. Samuel, (1991). The Third Wave: Democratization in the Late 21th Century. Johnston, M, (2003). Civil Society and Corruption: Mobilizing for Reform, Lanham, MD: Univesity Press of America 
Lestari, Didin Trinura, (2007). Sejarah Pembentukan Pemerintahan Kota Batu 2001, Jember: FKIP Universitas Jember.

Marijan, Kacung, (2010). Sistem Politik Indonesia: Konsolidasi Demokrasi Pasca-Orde Baru. Jakarta: Kencana Prenada Media Group.

O'donnell dan Schmitter, (1986). Transition from Authoritarian Rule: Comparative Prespective, Maryland, US: JHU Press.

Praseto, Muhanif, (2002). Islam dan Civil Society: Pandangan Muslim Indonesia, Jakarta: Gramedia Pustaka Utama.

Santoso, Riyadi, (1998). Pemerintaban Yang Bersib dan Masyarakat Madani, Yogyakarta: Tiara Wacana.

\section{Jurnal}

Alfitri, Rogaiyah, (2009) Demokrasi Indonesia: Mewujudkan Kesejabteraan atau Melabirkan Kesenjangan, Jurnal PPKn dan Hukum, Vol. 4, No.1, April 2009

Hyden, Goran, (1997). Civil Society, Social Capital and Development: Dissection of Complex Discourse, Studies in Comparative International Development, Vol.32, Issue.1. 1997

Karyono, (2016). “Korelasi Sistem Pilkada Dengan Perilaku Korupsi Kepala Daerah, Jurnal Harmony Vol. 1 No. 1. 2016

Kaufmann, Daniel, 2003. Indonesia Maintaining Stability, Deepening Reforms, Jakarta:

World Bank Report No. 27246-IND.

Moran, J. (2001). Democratic transitions and forms of corruption, Crime, Law and Social

Change, Vol. 36 No. 4, 2001

Rose, Shin. (2001). Democratization Backwards: The Problem of Third-Wave Democracies,

British Journal of Political Science Vol. 3 Issue 2 April 2001

Pietrzyk, D.I. (2003). Democracy or Civil Society? . Politics, Vol. 23 No. 1, 2003.

Suharko, (2005). Masyarakat Sipil, Modal Sosial dan Tata Pemerintahan Demokratis, Jurnal Ilmu Sosial dan Ilmu Politik, Vol.8 No.3, Maret 2005

Sukowiyono, Sulistiani (2014). Peran Malang Corruption Watch dalam Pelaksanaan Pendidikan Anti Korupsi di Malang Raya, Malang: FIS Universitas Negeri Malang 
TIM ICCE UIN JAKARTA. (2005). Demokrasi, Hak Asasi Manusia, dan Masyarakat Madani, Jakarta: Prenada Media.

World Bank, (2000). Anticorruption in Transition: A Contribution to the Policy Debate,

Washington

\section{Website}

Amonudin, Muhammad. Detik News. (2017). “Tiga Pasangan Calon Walikota Batu Laporkan Dana Kampanye ke KPUD”. Detik News. Rilis daring 13 Februari 2017 pada https://news.detik.com/berita-jawa-timur/d3420851/tiga-pasangan-calkota-batu-laporkan-dana-kampanye-ke-kpud.

Diakses 12 Desember 2017

Jurnal Malang. (2015). "Profil Malang Corruption Watch". Jurnal Malang. Rilis daring Mei 2015 pada http://www.jurnalmalang.com/2015/05/malangcorruption-watch-mcw-profil.html. Diakses 12 Desember 2017

Kompas. (2016). "Empat Pasang Calon Akan Bersaing di Pilkada Kota Batu 2017”. Kompas. Rilis daring 24 Oktober 2016 pada http://regional.kompas.com/read/2016/10/24/20434611/empat.pasan g.calon.akan.bersaing.di.pilkada.kota.batu.2017. Diakses 12 Desember 2017

Komisi Pemilih Umum Kota Batu. (2017) "Visi dan Misi”. Website Komisi Pemilihan Umum Kota Baru. Diakses 12 Desember 2017 pada http://kpukotabatu.go.id/statis-2-visidanmisi.html

Komisi Pemilih Umum Kota Batu. (2016). "Debat Publik Antar Pasangan Calon Walikota dan Wakil Walikota Batu Yang Pertama". KPU Kota Batu. Rilis daring 13 desember 2016, pada http://kpu-kotabatu.go.id/berita-530debat-publik-antar-pasangan-calon-walikota-dan-wakil-walikota-batuyang-pertama-.html

Komisi Pemilih Umum Kota Batu. (2016). “Jadwal Kampanye.” KPU Kota Batu. Rilis daring 31 oktober 2016, pada http://www.kpukotabatu.go.id/berita-438-jadwal-kampanye-.html

Komisi Pemilih Umum Kota Batu. (2016). "Launching Pilwali Kota Batu Tahun 2017 Berlangsung Dengan Semarak" KPU Kota Batu. Rilis daring 1 
Agustus 2016 pada http://kpu-kotabatu.go.id/berita-293-launcingpilwali-kota-batu-tahun-2017-berlangsung-dengan-semarak.html. Diakses 12 Desember 2017

Komisi Pemilih Umum Kota Batu. (2016). 'Persiapan Launching KPU Kota Batu Koordinasi Dengan Walikota Batu." KPU Kota Batu. Rilis daring 28 Juli 2016 pada http://kpu-kotabatu.go.id/berita-288-persiapan-launchingkpu-kota-batu-koordinasi-dengan-walikota-batu.html. Diakses 12 Desember 2017

Komisi Pemilih Umum Kota Batu. (2017). "Malang Corruption Watch (MCW) Kunjungi Kantor KPU Kota Batu”. KPU Kota Batu. Rilis daring 12 Januari 2017 pada http://kpu-kotabatu.go.id/berita-565-malangcorruption-watch-mcw-kunjungi-kantor-kpu-kota-batu-.html. Diakses 12 Desember 2017

Komisi Pemilih Umum Kota Batu. (2017). "Panwaslih Batu Resmi dilantik", KPU Kota Batu. Rilis daring 12 Juni 2017 pada http://kpukotabatu.go.id/berita-221-panwaslih-kota-batu-resmi-dilantik.html.

Diakses 20 Desember 2017

Komisi Pemilih Umum Kota Batu. (2017). "Panwaslih Batu Resmi Dilantik”. KPU Kota Batu. Rilis daring 12 Juni 2017 pada http://kpukotabatu.go.id/berita-221-panwaslih-kota-batu-resmi-dilantik.html.

Diakses 20 Desember 2017

Komisi Pemilih Umum Kota Batu. (2017). "Debat Publik Antar Pasangan Calon Walikota dan Wakil Walikota Batu Yang Kedua". KPU Kota Batu. Rilis daring 16 Januari 2017, pada http://kpu-kotabatu.go.id/berita-568debat-publik-antar-pasangan-calon-walikota-dan-wakil-walikota-batuyang-kedua.html. Diakses 20 Desember 2017

Liputan6. (2016). "Kasus Korupsi di Indonesia Menggila”. Liputan6. Rilis daring 7 April 2016, pada http://www.liputan6.com/news/read/2477341/kasuskorupsi-di-indonesia-menggila. Diakses 20 Desember 2017

Malang Corruption Watch. (2014). "Malang Corrution Watch Profil”. Malang Corruption Watch. Rilis daring Mei 2014 pada http://mcwmalang.org/arsip/2014/05/profil/. Diakses 20 Desember 2017 
Malangtoday. (2016). “Gelar Diskusi Publik, MCW: Pilkada Kota Batu Pintu Masuk Pemodal". Malangtoday. Rilis daring 22 November 2016, pada https://malangtoday.net/malang-raya/pilkada-kota-batu-pintu-masukpemodal/. Diakses 20 Desember 2017

Surabaya Pagi. (2014). "MCW Bongkar 11 Kasus Korupsi, ICW Siap Kawal". Surabaya Pagi. Rilis daring 21 Mei 2014 pada http://www.surabayapagi.com/WhiteCrime/114693/2014/05/21/MC W_Bongkar_11_Kasus_Korupsi,_ICW_Siap_Kawal.html\#. Diakses 20 Desember 2017

Surya Malang. (2016). "Inilah Jadwal Coblosan Pilkada Kota Batu”. Surya Malang. Rilis daring $15 \quad$ Februari 2016, pada http://suryamalang.tribunnews.com/2016/02/15/inilah-jadwalcoblosan-pilkada-kota-batu. Diakses 20 Desember 2017

\section{Undang-undang dan Peraturan Pemerintah}

Peraturan Presiden Republik Indonesia Nomor 12 tahun 1993 tentang Pembentukan Kota Administratif Batu

\section{Wawancara}

Wawancara dengan Atha Nursasi, (Malang, 27 Oktober 2017)

Wawancara dengan Atha Nursasi, (Malang, 18 Desember 2017)

Wawancara dengan Eky Maulana, (Malang, 18 Desember 2017) 